\title{
KEPUASAN MAHASISWA TERHADAP SISTEM PEMBELAJARAN ONLINE SELAMA MASA PANDEMIK COVID 19
}

Yessi Luanmase ${ }^{1}$, Jeanny Rantung ${ }^{2}$

Fakultas Keperawatan, Universitas Advent Indonesia

e-mail: yelvinluanmas1222@gmail.com

\begin{abstract}
ABSTRAK
Sistem pembelajaran ini membawa dampak besar dalam dunia pendidikan. Perubahan pembelajaran tersebut merupakan keadaan yang mengharuskan memasuki literasi informasi dalam budaya akademik. Perubahan model pendidikan konvensional, pertemuan tatap muka di ruangan kelas antara mahasiswa, dosen dan rekan mahasiswa menjadi model pembelajaran online. Jenis penelitian yang digunakan adalah penelitian deskriptif kualitatif pendekatan fenomenologi yang bertujuan untuk mendapatkan gambaran kepuasan mahasiswa Fakultas IImu Keperawatan (FIK) Universitas Advent Indonesia. Penetapan subyek penelitian menggunakan tehnik snowball throwing, data dikumpulkan dengan wawancara melalui telepon, analisa data menggunakan tehnik analisis isi. Hasil penelitian: selama masa pandemik Covid-19, mahasiswa melakukan pembelajaran secara mandiri dan aktif dengan menggunakan alat dan media pembelajaran online, dosen berperan sebagai fasilitator yang memberi motivasi selama pembelajaran, mahasiswa mengembangkan kemampuan personal, meskipun demikian ditemukan tantangan layanan internet yang sering mengganggu proses pembelajaran dan tambahan biaya kuota yang dikeluarkan mahasiswa. Secara umum, mahasiswa merasa puas dengan proses pembelajaran online, dimana pembelajaran online merupakan proses adaptasi yang berjalan terus seiring pandemik Covid-19 masih ada, baik mahasiswa maupun dosen bersama-sama berpartisipasi secara terbuka memasuki babak baru adaptasi "new normal".
\end{abstract}

Kata-kata kunci : Pandemik Covid-19, kepuasaan mahasiswa, pembelajaran online

\section{ABSTRACT}

This learning system has a big impact on the world of education. This learning change is a condition that requires entering information literacy in an academic culture. Changing the conventional education model, face-to-face meetings in classrooms between students, lecturers and fellow students has become an online learning model. This type of research is a qualitative descriptive study with a phenomenological approach which aims to get a picture of student satisfaction at the Faculty of Nursing (FIK) Advent Indonesia University. Determination of research subjects using snowball throwing techniques, data were collected by telephone interviews, data analysis using content analysis techniques. Research results: during the Covid-19 pandemic, students studied independently and actively using online learning tools and media, lecturers acted as facilitators who provided motivation during learning, students developed personal abilities, even so there were challenges in internet services that often interfere with the process. learning and additional quota costs incurred by students. In general, students are satisfied with the online learning process, where online learning is an adaptation process that continues as 
the Covid-19 pandemic still exists, both students and lecturers together openly participate in entering a new phase of "new normal" adaptation.

Key words: Covid-19 pandemic, student satisfaction, online learning 


\section{PENDAHULUAN}

\begin{tabular}{llr}
\multicolumn{1}{c}{ Sejak } & pandemi & Covid-19 \\
mengguncang & dunia & banyak \\
perubahan yang terjadi, & berbagai \\
antisipasi dilakukan & pemerintah \\
Indonesia & untuk & mencegah
\end{tabular} penyebaran virus korona (covid-19) ${ }^{(1)}$. merekomendasikan

untuk

menghentikan kegiatan dalam bentuk pertemuan-pertemuan yang berpotensi terjadinya kerumunan orang banyak untuk mencegah penyebaran covid-19. Salah satu sektor yang terdampak pandemi covid-19 adalah dunia pendidikan, dimana proses belajar mengajar melibatkan berkumpulnya mahasiswa dan dosen dalam satu ruangan, sehingga proses pembelajaran perlu ditinjau ulang pelaksanannya.

Berdasarkan surat edaran Kementrian Pendidikan dan Kebudayaan (Kemendikbud) Direktorat Pendidikan Tinggi No 1 tahun 2020 tentang pencegahan penyebaran Corona Virus Disease (Covid-19) di perguruan tinggi, memberi instruksi agar perguruan tinggi melakukan proses pembelajaran jarak jauh dan menyarankan mahasiswa untuk belajar dari rumah masing-masing agar proses belajar mengajar tetap berjalan. Prinsip kebijakan pendidikan di masa pandemi difokuskan pada kesehatan dan keselamatan peserta didik, pendidik, tenaga kependidikan, keluarga dan masyarakat. Proses belajar mengajar di perguruan tinggi harus tetap berjalan dengan kontak fisik minimal antara dosen dengan mahasiswa atau antara sesama mahasiswa baik di ruangan kelas maupun di lingkungan kampus. Proses pembelajaran ini memanfaatkan teknologi digital terutama dalam membantu dosen dan mahasiswa sehingga kegiatan pembelajaran tetap dapat berjalan walaupun tidak bertatap muka dan berada dalam tempat yang berbeda $^{(2)}$.

Pendidikan yang didukung oleh teknologi secara luas dikenal sebagai e-learning, atau dikenal juga sebagai pendidikan berbasis web, pendidikan virtual atau pengajaran yang didukung oleh teknologi informasi. Fitur pendidikan online adalah pembelajaran fleksibel yang meningkatkan pendidikan independen dan mandiri, peserta didik dapat memutuskan situs dan waktu belajar mereka, tanpa harus bertemu tatap muka ${ }^{(3)}$.

Pembelajaran online membutuhkan fasilitas-fasilitas seperti Telepon, Tablet, Labtop, yang digunakan untuk mendukung pelaksanaan pembelajaran secara online, misalnya kelas-kelas virtual yang menggunakan layanan Google Classroom, Edmodo, Schoology, dan aplikasi pesan instan seperti WhatsApp. Keuntungan penggunaan pembelajaran online adalah pembelajaran bersifat mandiri dan interaktivitas yang tinggi, mampu meningkatkan tingkat ingatan, memberikan lebih banyak pengalaman belajar, seperti teks, audio, video dan animasi yang semuanya digunakan untuk menyampaikan informasi, dan memberikan kemudahan menyampaikan, memperbarui isi, membantu mahasiswa, dalam mengirim email kepada mahasiswa lain, mengirim komentar pada forum diskusi, memakai ruang chat, hingga link videoconference untuk 
berkomunikasi secara langsung ${ }^{(4)}$.

$$
\text { Sistem pembelajaran ini }
$$

membawa dampak besar dalam dunia pendidikan. Perubahan pembelajaran tersebut merupakan keadaan yang mengharuskan memasuki literasi informasi dalam budaya akademik. Salah satu penyebab dari perubahan besar ini adalah dikarenakan pembelajaran online ini dilakukan secara tiba-tiba, hal ini berakibat besar pada kesiapan mahasiswa dalam melaksanakan pembelajaran yang belum memadai. Terlebih lagi akibat dari dampak pandemi corona yang melanda sehingga pembelajaran tidak berjalan maksimal karena harus tetap di rumah dan menerapkan physical distancing. Dan menyebabkan mahasiswa kurang puas dalam sistem pembelajaran yang dilakukan selama pandemi covid- $19^{(5)}$.

Penulis telah melakukan studi pendahuluan kepada 12 mahasiswa keperawatan dengan menanyakan pengalaman mahasisa dalam mengikuti proses pembelajaran secara online selamamasa pandemik covid-19. Sebanyak tujuh mahasiswa mengatakan bermasalah dengan kuota data internet, pembelajaran yang disampaikan kurang mengerti, dosen terlalu memberikan tugas yang banyak kepada mahasiswa, dan terlalu banyak tuntutan lain yang diberikan oleh dosen. Penelitian ini bertujuan untuk mengetahui gambaran kepuasan mahasiswa FIK Universitas Advent Indonesia Terhadap Sistem Pembelajaran online selama masa pandemi Covid-19.

\section{METODE PENELITIAN}

Jenis penelitian yang digunakan adalah penelitian deskriptif kualitatif melalui pendekatan fenomenologi. Penelitian kualitatif adalah penelitian yang berlandaskan filsafat post positivisme yang digunakan untuk meneliti kondisi objek yang alamiah dimana peneliti sebagai instrumen kunci dan hasil penelitiannya lebih menekankan makna dari pada generalisasi. Dalam penelitian ini, data yang dikumpulkan berupa kalimat dan penjabaran jawaban dari informan yang didapat melalui wawancara. Pengambilan subjek penelitian menggunakan metode snowball throwing. Informan penelitian terdiri dari 5 mahasiswaFakultas IImu Keperawatan Universitas Advent Indonesia yang masih aktif, yang terdiri dari :bagaimana pelaksanaan kegiatan sistem pembelajaran online pada masa pandemi covid-19, sarana atau alat media yang digunakan selama proses pembelajaran online, pandangan tentang kemampuan dosen dalam memberikan pembelajaran online, gambarkan pencapaian hasil pembelajaran yang peroleh selama proses pembelajaran, kendala atau tantangan dalam proses pembelajaran online, dan pendapat atau saran untuk meningkatkan proses pembelajaran online di FIK UNAI selama masa pandemi covid-19. Wawancara dengan informan menggunakan pertanyaan terstruktur, yaitu: bagaimana pengalaman mahasiswa dalam pelaksanaan pembelajaran online, bagaimana sarana atau alat media yang digunakan, bagaimana kemampuan dosen dalam memberikan pembelajaran online, bagaimana pencapaian hasil pembelajaran, apa saja yang menjadi tantangan selama pembelajaran online dan saran untuk meningkatkan proses pembelajaran online. Wawancara dilakukan secara online dengan menggunakan aplikasi 
video WhatsApp dan atas ijin informan wawancara tersebut direkam. Setelah wawancara selesai, peneliti memberitahu informan, setelah data dibuat menjadi transkrip, peneliti menghubungi kembali untuk melakukan validasi atau mengkonfirmasi data yang didapat. Setelah peneliti selesai mengumpulkan data, hasil wawancara didengar rekamannya kemudian di rangkum dalam bentuk transkrip. Setelah data selesai dianalisis dan dibuat transkrip, melakukan koding yang terbuka untuk mendapatkan kategori-kategori yang sesuai. Setelah itu mendeskripsikan fenomena yang telah didapat dari hasil penelitian secara narasi dan menyajikan data tersebut.

\section{HASIL PENELITIAN}

Hasil penelitian menemukan beberapa kategori utama kepuasan mahasiswa terhadap pembelajaran onlineselama masa pandemik covid-19, yaitu dua(2) kategori dan lima (5) sub kategori. Kategori tersebut berdasarkan teori belajar konstruktivismeyaitu: konstruktivisme kognitif, dan konstruktivisme sosial. Kategori tersebut berdasarkanteori belajar konstruktivisme yaitu: Konstruktivisme kognitif, Konstruktivisme sosial, sedangkan sub kategori yang didapatadalah: mahasiswa belajar mandiri, peran dosen memotivasi, mahasiswa mengembangkan kemampuan personal,media pembelajaran online, tantangan dalam pembelajaran online.

1. Konstruktivisme kognitif

Mahasiswa aktif belajar mandiri dalam meningkatkan dan mengembangkan ilmu yang diberikan dosen secara optimal, meskipun menggunakan sistem pembelajaran online adalah hal yang baru. Mahasiswa berusaha untuk menemukan dan merekonstruksikan pengetahuan dengan bantuan dan motivasi dosen sebagai fasilitator.

2. Konstruktivisme sosial

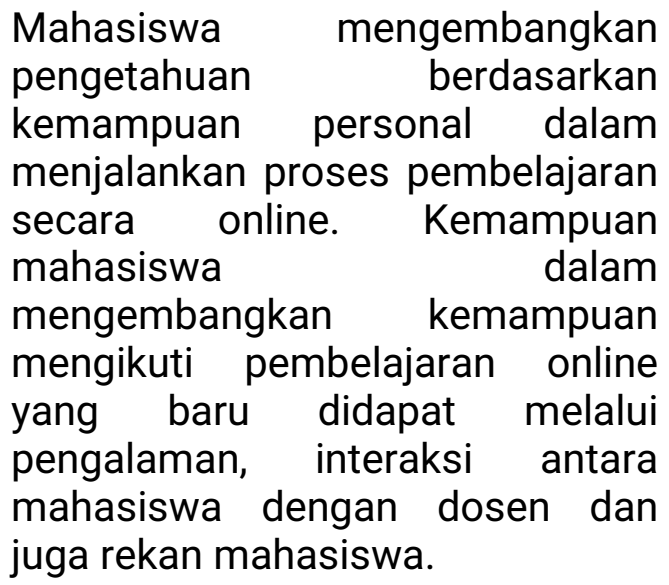

Dosen memberikan motivasi kepada mahasiswa untuk semangat mengikuti proses pembelajaran dengan metode yang beragam dalam menghadapi proses pembelajaran online. Proses pembelajaran online merupakan metode yang bergantung pada system telekomunikasi sehingga tidak perlu hadir di kelas atau tatap muka. Media pembelajaran online yang digunakan oleh mahasiswa meliputi: zoom, moodle, google dan whatsapp. Proses pembelajaran secara online memiliki beberapa masalah atau kendala yang dapat mengganggu proses pembelajaran. Tantangan yang paling sering dialami oleh mahasiswa selama mengikuti pembelajaran online adalah: internet, paket data atau kuota internet yang terbatas.

\section{PEMBAHASAN}

Hasil yang ditemukan berdasarkan wawancara, adalah mahasiswa dapat mengikuti proses pembelajaran online secara mandiri. Bila sebelumnya menjalankan proses pembelajaran konvensional secara tatap muka, berinteraksi langsung di 
ruangan kelas tetapi pada masa pandemik covid-19, mau tidak mau harus menyesuaikan diri mengikuti proses pembelajaran secara online. Menyesuaikan diri menghadiri pertemuan kelas menggunakan laptop atau handphone. Mahasiswa belajar secara mandiri tanpa bimbingandosen secara langsung, mencari informasi materi kelas atau tugas yang diberikan atau melakukan diskusi bersama rekan mahasiswa melalui aplikasi pesan instan $^{(2)}$. Pembelajaran secara online bersifat student centered bukan lagi berpusat pada guru, sehingga memotivasi mahasiswa untuk bertanggung jawab dan otonomi dalam belajar. Teori konstruktivisme memiliki konsep bahwa peserta didik membangun pemahaman dan pengetahuan mereka sendiri melalui interaksi pengetahuan yang ada di lingkungan mereka ${ }^{(6)}$. Sigit (2013) menambahkan bahwa pembelajaran konstruktivisme merupakan konsep pembelajaran berdasarkan sebuah pemahaman terhadap proses pembelajaran yang dilalui siswa adalah proses merekonstruksi sebuah pengetahuan serta pengalaman yang dilakukan dan dilalui siswa (7). Pembelajaran berpusat pada mahasiswa yang dilakukan secara online merupakan kenyataan bahwa pembelajaran dilakukan tanpa ada batasan ruang dan waktu ${ }^{(8)}$. Meskipun dosen memiliki peran terbatas dalam pembelajaran online, dosen berperan sebagai fasilitator, bertanggungjwab memberi motivasi pada mahasiswa untuk membangun dan mengeksplorasi pengetahuan secara aktif (9). Peserta didik harus menentukan kualitas pembelajaran dan bertanggung jawab atas hasil belajar sendiri (8). Pembelajaran konstruktivisme menuntun siswa untuk pemahaman yang lebih tinggi melalui catatan-catatan yang mereka tulis dengan menggunakan kata-kata sendiri ${ }^{(10)}$.

Proses pembelajaran online di masa pandemik covid-19 menuntut mahasiswa untuk dapat mengembangkan pengetahuan berdasarkan kemampuan yang dimiliki. Mahasiswa menggunakan alat-alat pendamping dalam belajar selain buku, terdapat media sosial, media pembelajaran dan yang lainnya. Selain menggunakan alat bantu, mahasiswa juga berinteraksi dengan rekan mahasiswa, orang yang berpengalaman atau orangtua untuk mendapat bantuan dan informasi terhadap materi pembelajaran atau hal -hal lain yang belum dipahami. Melalui media pembelajaran atau media sosial, melakukan interaksi dengan orang lain akan menghasilkan pengalaman praktik, solusi pembelajaran yang baru. Berdasarkan teori Vygotsky konstruktivisme sosial menyoroti bahwa interaksi sosial dan aktivitas individu dalam ruang lingkup kultural dapat menentukan perkembangan dan pengetahuan. Individu membangun pengetahuan berdasarkan pemahaman atau pengetahuan melalui interaksi pengetahuan yang ada dan lingkungan sekitar ${ }^{(8)}$. Individu adalah proses belajar yang unik, memiliki kebutuhan dan latarbelakang yang unik pula. Kegiatan belajar dipengaruhi oleh bahasa dan tindakan dalam kondisi sosial. Bahasa memiliki fungsi sangat penting dalam proses komunikasi sosial yang diawali dengan proses mengindra terhadap simbol dan tanda (10). Pembelajaran di masa pandemi akan menyebabkan perkembangan historis dan sistem simbol seperti logika berpikir ketika belajar secara online, keadaan ini diwariskan peserta didik yang harus dihadapi dan dipelajari sepanjang kehidupan. Sehingga penting terjalin interaksi sosial yang harmonis antara peserta didik, keluarga dan terlebih pada lingkungan yang memiliki pengetahuan 
yang luas. Tanpa interaksi sosial, peserta didik tidak akan memperoleh makna sosial dari sistem simbol yang sangat penting dan dapat belajar bagaimana memanfaatkannya sebagai pengetahuan (11). Dalam teori konstruktivisme sosial, seorang pendidik berperan sebagai penyalur budaya, mediator untuk mendukung proses pembentukan dan membangun pengetahuan siswa, yang dikenal dengan istilah Zona of Proximal Development (ZPD) (8),(10). Dosen berperan dalam mengembangkan potensi peserta didik, memberi ruang kepada siswa untuk berkreasi menuangkan ide-ide dan secara sadar telah menggunakan strategi belajar mereka sendiri. Pendidik atau dosen harus mampu untuk mendorong peserta didik untuk belajar dengan metode yang aktif, otentik, bermakna dan konstruktif. Sebagai fasilitator, dosen memantau dan menyediakan lingkungan belajar online yang aman, positif dan memastika semua mahasiswa memiliki kesempatan untuk mengikuti diskusi dan kegiatan kelas.

Pembelajaran online tentu saja membutuhkan dukungan perangkat mobile seperti telepon selular, tablet, dan laptop untuk mendapatkan akses sumber informasi dimana saja dan kapan saja (12). Untuk tercapainya tujuan pembelajaran online di FIK Universitas Advent Indonesia, menggunakan berbagai media kelas virtual, seperti: Zoom, Google Classroom; aplikasi pesan instan dan video yang sering digunakan adalah WhatsApp, aplikasi pembelajaran Moodle atau melalui media sosial seperti Facebook, Youtube. Penggunaan perangkat dan media dalam pembelajaran online tidak menjadi masalah bagi mahasiswa, karena semua mahasiswa memiliki telepon selular sebagian besar memiliki laptop, dan sudah terbiasa mengoperasikannya. Penggunaan laptop atau telepon seluler memberikan kemudahan dan jaminan mobilitas dan fleksibilitas sehingga memungkinkan mahasiswa mengikuti perkuliahan dari mana saja, dan kapan saja. Fasilitas penyimpanan yang ditawarkan oleh laptop atau telepon seluler memberikan kemudahan bagi mahasiswa untuk menyimpan materi yang diberikan dosen dan dapat mengakses kembali apabila diperlukan. Penelitian yang dilakukan oleh Sun et al (2008) menemukan bahwa kepuasan mahasiswa terhadap pembelajaran online dipengaruhi oleh fleksibilitas, waktu, lokasi dan metode pembelajaran online ${ }^{(6)}$.

Pembelajaran online juga memiliki tantangan, seperti ketersediaan layanan internet yang kurang memadai sehingga tejadi gangguan sinyal yang membuat mahasiswa tidak mendapatkan materi perkuliahan secara lengkap, informasi kuliah terlambat atau mengumpulkan tugas tidak tepat waktu. Tantangan yang lain adalah ketersediaan kuota internet yang terbatas, sehingga tidak dapat mengikuti pemaparan materi secara online.

Dalam proses pembelajaran online, tantangan lain yang ditemukan adalah mahasiswa mengalami kesulitan dalam memahami materi kuliah yang diberikan, mahasiwa mebutuhkan penjelasan secara verbal dari dosen, tetapi penjelasan yang diberikan tidak dapat memberikan penjelasan menyeluruh terhadap materi yang sedang dibahas. Komunikasi dosen melalui aplikasi pesan instan atau pada kolom diskusi yang tersedia pada aplikasi kelas virtual tidak mampu memberi penjelasan menyeluruh terhadap materi yang sedang dibahas ${ }^{(2),(13)}$.

KESIMPULAN 
Pembelajaran secara online di masa Pandemi Covid-19 membuat perubahan yang cukup besar dalam proses pembelajaran di FIK Universitas Advent Indonesia. Perubahan model pendidikan konvensional, pertemuan tatap muka di ruangan kelas antara mahasiswa, dosen dan rekan mahasiswa menjadi model pembelajaran online yang fleksibel dalam waktu dan ruang (tempat).

Mahasiswa secara umum merasa puas dengan pembelajaran online terutama dalam pelaksanaan pemeblajaran yang lebih fleksibel. Mahasiswa bertanggungjawab dan mandiri dalam menjalankan pembelajaran, mendapatkan motivasi dari dosen untuk lebih aktif mengeksplorasi dan meningkatkan kemampuan kognitif. Meskipun dosen lebih banyak berperan sebagai fasilitator, melakukan interaksi dengan mahasiswa tetapi tetap menunjukkan kemampuannya untuk memantau dan menyediakan lingkungan belajar online yang aman, positif dan memberi motivasi sebagai tutor untuk memberikan keterampilan dan pengetahuan kepada setiap mahasiswa. Meskipun dalam pelaksanaan pembelajaran online, terdapat hal-hal yang menjadi tantangan, seperti layanan internet yang sering mengganggu proses pembelajaran dan tambahan biaya kuota yang dikeluarkan mahasiswa.

Pembelajaran online merupakan proses adaptasi yang berjalan terus seiring pandemik Covid-19 yang masih ada, baik mahasiswa maupun dosen bersama-sama berpartisipasi secara terbuka memasuki babak baru adaptasi "new normal."

\section{DAFTAR PUSTAKA}

(1) Kementerian Kesehatan. (2020). . Pedoman pencegahan dan pengendalian coronavirus disease (Covid-19). 1(3), 31-116

(2) Firman, F., \& Rahayu, S. (2020). Pembelajaran Online di Tengah Pandemi Covid-19. Indonesian Journal of Educational Science (IJES), 2(2), 81-89. https://doi.org/10.31605/ijes.v2i 2.659

(3) Hoq, M. (2020). E-Learning During the Period of Pandemic (COVID-19) in the Kingdom of Saudi Arabia: An Empirical Study. American Journal of Educational Research, 8, 457-464

(4) Windhiyana, P. (2020). Dampak covid-19 terhadap kegiatan pembelajaran online disebuah perguruan tinggi Kristen di Indonesia. Journal of Perspektif IImu Pendidikan, 34, 1

(5) Arizona, K. A. Z. \& R. R. (2020). Pembelajaraan Online Berabasis Proyek salah satu SolusiKegiatan Belajar Mengajar Di Tengah Pndemic Covid -19. . . Jurnal IImiah Profesi Pendidikan, 5(1), 64-70

(6) Sun, P. C., Tsai, R. J., Finger, G., Chen, Y. Y., \& Yeh, D. (2008). What drives a successful eLearning? An empirical investigation of the critical factors influencing learner satisfaction. Computers and Education.

https://doi.org/https://doi.org/10. 1016Zj.compedu.2006.11.007

(7) Sigit, M. W. (2013). Pembelajaran Konstruktivisme Teori dan Aplikasi Pembelajaran dalam Pembentukan Karakter. Bandung: Alfabeta

(8) Hong, Z. (2003). Constructivism in online learning: a literature review. 853.

https://doi.org/https:// scholarworks.uni.edu/grp/853 Sun

(9) Liu, C. C., \& Chen, I. J. (2010). Evolution of constructivism. 
Contemporary issues in education research. 4(3), 63-66.

(10) Muhibbin., Hidayatullah, M. (2020). Implementasi teori Belaar Konstruktivisme Vygotsky Pada Mata Pelajaran Pai di SMA sains Qur'an Yogyakarta. 5(10), 113-130.

(11) Ichsan, A. S. (2020). Pandemi Covid-19 dalam Telaah Kritis Sosiologi Pendidikan. Mgistra. Jurnal Keguruan Dan IImu Pendidikan, 4(7), 98-114. https://doi.org/http://ejournal.un mus.ac.id/index.php/magistra

(12) Gikas, J., \& Grant, M. M. (2013). Mobile computing devices in higher education: Student perspectives on learning with cellphones, smartphones \& social media Internet and Higher Education.

https://doi.org/https://doi.org/10. 1016/jjheduc.2013.06.002

(13) Sadikin, A., Hamidah, A. (2020). Pembelajaran Daring di Tengah Wabah Covid-19. Biodik. Jurnal Ilimiah Pendidikan Biologi., 6(20), 214-224.

https://doi.org/https://onlinejournal.unja.ac.id/biodik 